\title{
Urethroplasty in the management of urethral strictures: a literature review
}

\author{
Wedyan Salem Basaif ${ }^{1 *}$, Ali Ahmed Madkhali², Ahmed Ibrahim Almania ${ }^{3}$, \\ Raed Abdullah Mohammed ${ }^{3}$, Manar Mohammed Alshahrani ${ }^{4}$, Abdullah Mohammed Al Jabir ${ }^{5}$, \\ Abdullah Mohammed Almohammadi ${ }^{6}$, Hatem Ali Alkazman ${ }^{7}$, Raghad Abdulelah Alsayed ${ }^{8}$, \\ Ahad Yaseen Azhar', Omar Safar Alshahrani ${ }^{10}$, Faisal Ahmed Alkhathami ${ }^{11}$
}

\author{
${ }^{1}$ Department of Urology, ${ }^{4}$ General Practitioner, King Fahad General Hospital, Jeddah, Saudi Arabia \\ ${ }^{2}$ Department of Emergency Medicine, King Fahad Central Hospital, Jazan, Saudi Arabia \\ ${ }^{3}$ College of Medicine, King Khalid University, Abha, Saudi Arabia \\ ${ }^{5}$ General Practitioner, Ministry of Health, Khamis Mushait, Saudi Arabia \\ ${ }^{6}$ Department of Urology, King Fahad Hospital, Medina, Saudi Arabia \\ ${ }^{7}$ General Practitioner, Ministry of Defense, Riyadh, Saudi Arabia \\ ${ }^{8}$ Department of Urology, Ohoud hospital, Medina, Saudi Arabia \\ ${ }^{9}$ College of Medicine, Batterjee Medical College, Jeddah, Saudi Arabia \\ ${ }^{10}$ Department of Urology, Armed Forces Hospital Southern Region, Khamis Mushait, Saudi Arabia \\ ${ }^{11}$ General Practitioner, Ministry of Health, Riyadh, Saudi Arabia
}

Received: 19 December 2020

Accepted: 04 January 2021

*Correspondence:

Dr. Wedyan Salem Basaif,

E-mail: wedyanbasaif@gmail.com

Copyright: () the author(s), publisher and licensee Medip Academy. This is an open-access article distributed under the terms of the Creative Commons Attribution Non-Commercial License, which permits unrestricted non-commercial use, distribution, and reproduction in any medium, provided the original work is properly cited.

\begin{abstract}
Urethral stricture is defined as pathological urethral narrowing caused by corpus spongiosum fibrosis. The etiology of this condition is mostly idiopathic, which can also result from iatrogenic (like previous urethral surgeries, catheterization, or resection), inflammatory and traumatic causes. The evidence discussing the management of urethral strictures is scarce. The management starts with an appropriate evaluation of the condition through a comprehensive history taking (obstructive symptoms) and physical examination. Diagnostic investigations include cystoscopy (the most specific), urethrography, patient reported scales, like American urological association symptom index, uroflowmetry, and retrograde urethrography. Previous literature shows urethroplasty is cost effective, whether when it is used as the primary treatment or following a non-successful dilation and direct visualization internal urethrotomy. Moreover, open urethroplasty and endoscopic urethrotomy were comparable among both procedures in terms of voiding improvement; however, urethroplasty benefit was more durable. Akin to that, urethroplasty was found to be a successful procedure in up to $95 \%$ of the cases with the appropriate experience level. Although excision and primary anastomosis and augmentation/substitution urethroplasties have considerable long-term success rates, the EPA procedures have a controversial influence on sexual function, which may be unacceptable to some reconstructive urologists. In general, there are a few large scales, multi center studies that can produce high-quality evidence. There is an urge to develop more high-grade research in terms of ideal management of urethral strictures.
\end{abstract}

Keywords: Urethral stricture, Urethroplasty, corpus spongiosum fibrosis

\section{INTRODUCTION}

Urethral stricture is defined as pathological urethral narrowing caused by corpus spongiosum fibrosis. ${ }^{1}$ The etiology of this condition is mostly idiopathic, which can also result from iatrogenic (like previous urethral surgeries, catheterization, or resection), inflammatory and traumatic causes. ${ }^{2}$ In the USA, procedures done to 
manage urethral strictures are estimated to cost 200 million dollars, for five thousand patients, every year. ${ }^{3}$ In the same context, the UK has an annual number of urethroplasties and urethrotomies dilatation procedures as high as 700 and 16 thousand, respectively. ${ }^{4}$ In addition to the direct costs, the urethral strictures-associated morbidities will increase this burden; including infections, incontinence, and possible recurrence. ${ }^{2}$ The evidence discussing the management of urethral strictures is scarce. The large scale studies on this topic are not abundant and neither the European association of urology (EAU) or the British association of urological surgeons (BAUS) have published final management guidelines. To date, only the Société Internationale d'urologie (SIU) and the American urological association (AUA) had released official guidelines for the urethral strictures in 2010 and 2016, respectively. ${ }^{5-9}$ Both societies recommended the urethroplasty as the absolute treatment in urethra strictures recurrence and the first line one in some cases (as penile strictures and hypospadias). ${ }^{5-9}$ However, there were some differences in terms of recurrent strictures, where the AUA advocates arthroplasty in all cases of recurrent urethral strictures, while the SIU recommends the endoscopic procedures in some specific conditions. ${ }^{5-9}$ Recently, the results of the "open" trial were published, which is a randomized, multi-center trial; aiming to compare the outcomes of open urethroplasty and endoscopic urethrotomy in the management of recurrent bulbar urethral strictures. ${ }^{10}$ Their results showed the results were comparable among both procedures in terms of voiding improvement; however, urethroplasty benefit was more durable. ${ }^{10}$ Based on the aforementioned glimpse of the available evidence, it seems that the management of urethral strictures is not fully established. For that, we aim to provide a comprehensive summary of the most significant pieces of literature in terms of urethroplasty as a management procedure for urethral strictures. An extensive literature search of the Medline, Cochrane, and EMBASE databases was performed on 5 December 2020 using the medical subject headings (MeSH) or a combination of all possible related terms. Studies reporting the urethroplasty as a management procedure for urethral strictures were screened for relevant information. We did not pose any limits on date, language, or publication type.

\section{MANAGEMENT OF URETHRAL STRICTURES}

\section{Management algorithm and initial evaluation}

The possible management lines for urethra strictures based on different sizes and sites is shown in (Figure 1). ${ }^{11}$ The management starts with an appropriate evaluation of the condition through a comprehensive history taking and physical examination. ${ }^{11}$ Men would usually suffer from obstructive symptoms like difficulty to void, weakened urine stream, and inability to empty the bladder completely. ${ }^{11}$ Urethral strictures' patients may also suffer from urinary stones and infection. ${ }^{11}$ Useful diagnostic tools, to be done prior to an intervention, include cystoscopy (the most specific) and urethrography (to detect stricture's length and location). ${ }^{6,12,13}$ According to the AUA recommendations, urethral stricture should be considered among the possible diagnoses when a patient is presenting with any of the aforementioned symptoms; however, the SIU does not have a direct comment on this matter. ${ }^{5-9}$ The two guidelines advise to use the patient reported scales, like the AUA-symptom index (AUA-SI), along with uroflowmetry for the assessment of urethral strictures; nevertheless, AUA-SI is only an adjuvant diagnostic tool and should be used alone..$^{5-9}$ In specific, a reduction in peak flow is a finding suggestive of urethral strictures so, imaging is recommended as the next step. ${ }^{14}$ For the radiographic evaluation, AUA recommendations state that a retrograde urethrography is the primary diagnostic measure for urethral strictures which would help in detecting the presence of other urethral pathologies; however, is really dependent on the operator. $^{6,15}$ On the other hand, the SIU recommends cystoscopy as the most specific evaluating tool but it should be noted that it cannot be used used to assess how long the stricture is. ${ }^{13}$ Similarly, ultrasound can be also used to define the spongiofibrosis extent and determine the stricture length. ${ }^{16}$ According to the AUA, ultrasound can be used alone for this purpose, while the SIU guidelines recommend that a retrograde urethrography should be used as an adjuvant procedure for a proper preoperative assessment (Table 1).,16

\section{Urethroplasty compared to other procedures}

Initially, endoscopically-performed urethrotomy was the primary management for urethral strictures, by incising the present scar tissue to increase the width of the urethral lumen which will allow secondary intention healing. ${ }^{17,18}$ Nevertheless, many reports found high recurrence rates among patients managed with this procedure, reaching up to $60 \% .^{17,18}$ Moreover, a randomized clinical trial found that endoscopically performed urethrotomy has high recurrence rates similar to those found by the "historical" urethral bougienage procedures. ${ }^{19}$ Urethroplasty is the definitive management option for urethral strictures and has success rates ranging from $80 \%$ to $90 \%$, depending on the complexity of the repairs done. ${ }^{20}$ The previous literature shows urethroplasty is cost-effective, whether when it is used as the primary treatment or following a non-successful dilation and direct visualization internal urethrotomy (DVIU). ${ }^{21-23}$ One study found that open urethroplasty and endoscopic urethrotomy were comparable among both procedures in terms of voiding improvement; however, urethroplasty benefit was more durable. ${ }^{10}$ Akin to that, urethroplasty was found to be a successful procedure in up to $95 \%$ of the cases with the appropriate experience level. ${ }^{24-26}$ These findings paved the way for urethroplasty as a suggested procedure for better outcomes. Over the past few years, the advances in urethroplasty procedures are in terms of improving the management algorithm and optimizing the technique (Figure 1). 
Table 1: Summary of recommendations by management category.

\begin{tabular}{|c|c|c|c|}
\hline $\begin{array}{l}\text { Management } \\
\text { category }\end{array}$ & AUA & Both & SIU \\
\hline $\begin{array}{l}\text { Clinical } \\
\text { evaluation }\end{array}$ & $\begin{array}{l}\text { Stricture is in the differential in } \\
\text { a patient presenting with } \\
\text { LUTS* }\end{array}$ & $\begin{array}{l}\text { Symptoms, patient-reported } \\
\text { outcomes and uroflow can be } \\
\text { helpful in diagnosis }\end{array}$ & $\begin{array}{l}\text { Uroflow is unreliable in pediatric } \\
\text { patients }\end{array}$ \\
\hline $\begin{array}{l}\text { Radiographic } \\
\text { and } \\
\text { cystoscopic } \\
\text { evaluation }\end{array}$ & $\begin{array}{l}\text { In non-urgent situations, } \\
\text { determine the length and } \\
\text { location of stricture }^{\#}\end{array}$ & $\begin{array}{l}\text { RUG/VCUG and cystoscopy } \\
\text { are the best tests for } \\
\text { diagnosis and } \\
\text { characterization*+; } \\
\text { ultrasound can be used for } \\
\text { spongiofibrosis and stricture } \\
\text { length* }\end{array}$ & MRI/CT can be used as an adjunct* \\
\hline $\begin{array}{l}\text { Endoscopic } \\
\text { management }\end{array}$ & $\begin{array}{l}\text { Catheter removal within } 72 \\
\text { hours after DVIU*; recommend } \\
\text { against repeat DVIU }\end{array}$ & $\begin{array}{l}\text { DVIU and dilation have } \\
\text { equivalent outcomes*; DVIU } \\
\text { can be offered for untreated, } \\
\text { short }(<2 \mathrm{~cm}) \text { bulbar } \\
\text { strictures*+; repeat DVIU } \\
\text { with CIC can be palliative*^ }\end{array}$ & $\begin{array}{l}\text { Repeat DVIU can be considered } \\
\text { with favorable strictures if the time } \\
\text { to recurrence is }>3 \text { months } \text {; avoid } \\
\text { DVIU in obliterative strictures \& } \\
\text { pediatric patients }{ }^{+} \text {; repeat DVIU can } \\
\text { exacerbate spongiofibrosis }\end{array}$ \\
\hline Urethroplasty & $\begin{array}{l}\text { Urethroplasty should be done by } \\
\text { experts or patients referred to } \\
\text { experts }{ }^{\#} \text { meatal strictures can } \\
\text { be treated with initial } \\
\text { dilation/meatotomy but } \\
\text { recurrences should undergo } \\
\text { urethroplasty*; buccal mucosa } \\
\text { is the graft of choice }\end{array}$ & $\begin{array}{l}\text { Long }(>2 \mathrm{~cm}) \text {, previously } \\
\text { treated or penile strictures } \\
\text { should be treated with } \\
\text { urethroplasty }{ }^{*^{\wedge}} \text {; do not } \\
\text { tubularize grafts }{ }^{\#+} \text {; skin flaps } \\
\text { can be used but avoid hair- } \\
\text { bearing skin }{ }^{\#+} ; \text { avoid } \\
\text { allografts or xenografts }\end{array}$ & $\begin{array}{l}\text { EPA has a high success rate for } \\
\text { short bulbar strictures }{ }^{+} ; \text {the success } \\
\text { rate of EPA is greater than } \\
\text { substitution urethroplasty }{ }^{+} \text {; success } \\
\text { rates of EPA for longer strictures } \\
(2-4 \mathrm{~cm}) \text { are higher in the proximal } \\
\text { bulbar urethra ; grafts are preferred } \\
\text { over flaps^; hypospadias strictures } \\
\text { should be treated with } \\
\text { urethroplasty^ }\end{array}$ \\
\hline $\begin{array}{l}\text { Pelvic } \\
\text { fracture } \\
\text { urethral } \\
\text { injury }\end{array}$ & $\begin{array}{l}\text { Delayed formal reconstruction } \\
\text { should be performed after major } \\
\text { injuries are stabilized and are } \\
\text { preferred over delayed } \\
\text { endoscopic management }{ }^{\#} \text {; prior } \\
\text { to reconstruction, } \\
\text { RUG/VCUG/cystoscopy should } \\
\text { be performed to assess stricture } \\
\text { characteristics* }\end{array}$ & - & $\begin{array}{l}\text { Rule out UI with blood at meatus+; } \\
\text { suspect UI with pelvic fracture } \\
\text { RUG is the test of choice }{ }^{+} \text {; DRE } \\
\text { unreliable for UI^; in stable patients, } \\
\text { one can attempt a gentle catheter } \\
\text { placement } \text {; early on, endoscopic } \\
\text { realignment can be attempted }{ }^{\wedge} \text {; early } \\
\text { urethroplasty should be avoided } \\
\text { except with concurrent } \\
\text { rectal/bladder neck injury }\end{array}$ \\
\hline $\begin{array}{l}\text { Bladder neck } \\
\text { contracture }\end{array}$ & $\begin{array}{l}\text { An open reconstruction is an } \\
\text { option for recalcitrant BNC* }\end{array}$ & $\begin{array}{l}\text { BNC can be managed } \\
\text { endoscopically* }\end{array}$ & - \\
\hline $\begin{array}{l}\text { Lichen } \\
\text { sclerosis }\end{array}$ & $\begin{array}{l}\text { Biopsy when cancer is } \\
\text { suspected }^{\#}\end{array}$ & $\begin{array}{l}\text { Use buccal mucosa to } \\
\text { reconstruct urethral stricture, } \\
\text { not genital } \operatorname{skin}^{+^{\wedge}}\end{array}$ & $\begin{array}{l}\text { If LS is confined to glans/foreskin, } \\
\text { topical steroids and circumcision are } \\
\text { appropriate+; do not use colonic or } \\
\text { bladder mucosa*; long term follow } \\
\text { up is needed secondary to the risk of } \\
\text { malignancy }\end{array}$ \\
\hline $\begin{array}{l}\text { Alternatives } \\
\text { to } \\
\text { urethroplasty }\end{array}$ & $\begin{array}{l}\text { A perineal urethrostomy is an } \\
\text { option for strictures* }\end{array}$ & - & $\begin{array}{l}\text { Urethral stenting can be offered to } \\
\text { patients who cannot tolerate } \\
\text { urethroplasty or } \mathrm{CIC}^{\wedge}\end{array}$ \\
\hline Follow up & $\begin{array}{l}\text { Important to monitor for } \\
\text { symptomatic stricture } \\
\text { recurrence }^{\#}\end{array}$ & - & $\begin{array}{l}\text { Urethrography or urethroscopy can } \\
\text { be used to monitor recurrence }{ }^{+}\end{array}$ \\
\hline
\end{tabular}

AUA: American urological association; SIU: Société Internationale d'Urologie; PFUI: pelvic fracture and urethral injury; DVIU: direct vision internal urethrotomy; VCUG: voiding cystourethrogram; LS: lichen sclerosis; RUG: retrograde urethrogram; EPA: excision primary anastomosis; LUTS: lower urinary tract symptoms; CIC: clean intermittent catheterization. +: Grade A (Well-conducted RCT or exceptionally strong observational study); ${ }^{\wedge}$ : Grade B (RCT with some weakness of procedure or generalizability or generally strong observational studies); *: Grade C (Observational studies that are inconsistent, have small sample sizes, or have other problems that potentially confound interpretation of data); \#: clinical principal/expert opinion, if 2 grades are listed: AUA is listed first. 


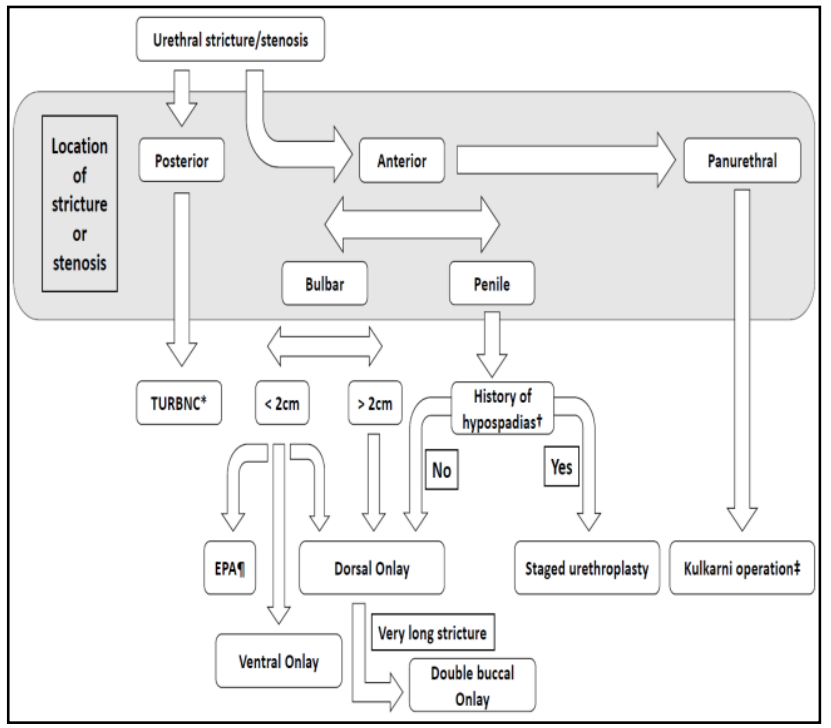

Figure 1: Urethral stricture treatment algorithm, considering mitomycin $\mathrm{C}$ installation during the time of transurethral resection of a bladder neck contracture. Employ caution; this technique has a high sexual complication rate, †urethra is completely obliterated, + dorsal onlay buccal urethroplasty with unilateral urethral dissection and penile inversion through a perineal incision.

\section{TYPES OF URETHROPLASTY}

\section{Excision and primary anastomosis urethroplasty}

Excision and primary anastomosis (EPA) urethroplasty include the excision of the scarred urethral tissue, followed by spatualtion of proximal and distal health ends to provide a patent tract. ${ }^{11}$ A fifteen-year follow-up, this procedure shows a high success rate of $86 \%$ with a low rate of associated complications. ${ }^{27}$ The EPA urethroplasty is usually used in short bulbar urethra strictures $(<2 \mathrm{~cm})$; however, few reports suggesting using it for longer strictures with success rates comparable to the EPA techniques. ${ }^{28,29}$ Although the usage of urethroplasty for short bulbar strictures has remarkable success rates up to $95 \%$, there is evidence suggesting buccal urethroplasty as an alternative with lower sexual complications. ${ }^{30,31}$

There are some possible drawbacks to the EPA procedure in terms of sexual functionality; including erectile dysfunction (ED), ejaculation problems, insensitive/cold/soft glans, reduction of the penis length, and chordee. ${ }^{11,26,29,31,32}$ The rates of these sexual complications are lower among buccal urethroplasty patients compared to the EPA ones; however, it was found that the level of ED is low following the EPA and the urethral transection could not be the etiology of sexual dysfunction. ${ }^{31,33-35}$ To reduce such complications a modified technique was developed with doing anastomotic urethroplasty without urethral transections, hence, preserving the corpora spongiosum and the blood supply. ${ }^{36}$

\section{Augmentation/substitution urethroplasty}

Substitution graft urethroplasty is a definitive treatment technique for short urethral stricture and strictures longer than $2 \mathrm{~cm}$. Its exposure is similar to EPA exposure, but it differs from EPA in graft place. In Substitution graft urethroplasty, the graft is located inside the narrowed urethral lumen then it is sutured to the opposite side of the incised lumen which effectively helps in expanding the luminal diameter. In this technique, the most used material as a graft is buccal mucosa, however, an inguinal graft can be used. ${ }^{37-39}$ When Graft Onlay urethroplasty is used in the bulbar urethra, its success rate is about $90 \% .{ }^{40}$ The graft may be used ventrally, dorsally, or combined. Regarding the ventral onlay, the blood supply is provided by the corpus spongiosum and by in corpora cavernosum one. ${ }^{37-39}$ The spongiosal tissue is strong enough to support the graft and has enough thickness to close the tunica spongiosum over the graft. This method allows for less dissection than the dorsal technique. ${ }^{41,42}$ On the other hand, dorsal onlay is used in all locations of the urethra especially in the thinner urethra of the distal bulb. The dorsal approach is widely used even in even pan-urethral strictures. The urethra is mobilized unilaterally (Kulkarni method) or completely dissected from the corpora (Barbagli method). If the urethra is mobilized unilaterally, the neurovascular of the urethra is unilaterally preserved. ${ }^{43}$ In a structure of $4-7 \mathrm{~cm}$ in length, a single buccal graft is used and for longer ones, additional lingual or buccal grafts are used. ${ }^{43}$

Some experts prefer to use the dorsal approach regardless of the site or the position of the stricture as it has fewer rates of diverticulum formation. ${ }^{44}$ Additionally, they believe that dorsal grafts have better support. ${ }^{44}$ However, a lot of studies showed that both techniques have the same success rates. ${ }^{45-49}$ When the stricture becomes longer $(6-8 \mathrm{~cm})$, ventral onlay success rates fall. In this case, a double (combined) buccal graft urethroplasty is proposed in order to decrease failure rates. ${ }^{50}$ The double graft repair is useful in nearly obliterated strictures where ventral approach comes with high failure rates. ${ }^{51}$

\section{Kulkarni operation}

In 2000, Kulkarni et al have described a new one-stage repair method of very long and pan-urethral strictures. They used a penile inversion exposure and buccal mucosal grafts. ${ }^{52}$ In this approach, a unilateral mobilization is used to keep the urethral blood supply intact. $^{43}$ The penile tissue is invaginated by a perineal incision, which exposes all the urethra till the glans and this is the same as the exposure in urethrectomy. ${ }^{52}$ This optimized method has a high satisfaction rate in treating the worst types of strictures and replaces the use of fasciocutaneous flaps or the former staged, highly morbid urethroplast. This procedure has an $80-83 \%$ long-term success rate, however, being used in conditions that increases failure rates as failed previous urethroplasty, lichen sclerosus or very long strictures. ${ }^{53-55}$ 


\section{Johanson technique}

Patients, who suffer from dense lichen sclerosus related strictures, complete obliteration of the lumen, or previously had a hypospadias repair, are a true challenge owing to the poor blood supply and scarring. ${ }^{55,56}$ This two-staged method with buccal graft is used to treat these sorts of strictures with success. The first stage is performed by opening the urethra at the meatus and securing the urethral edges till the penile skin then widening the circumference through suturing the buccal graft to the lateral margins of the urethral plate. The second stage involves tubularizing or closing or the previously opened urethra. This approach is best used in patients who had a previous hypospadias repair and when severe lichen sclerosus or obliterated strictures are present. Buccal grafts increase the success rate of this technique from 33 to $85 \% .^{57-59}$

\section{GUIDELINES FOR USING URETHROPLASTY IN URETHRAL STRICTURES' MANAGEMENT}

The summary of the official AUA and SIU recommendations is presented in (Table 1). ${ }^{1}$

\section{Bulbar strictures}

As per the SIU recommendations, the EPA urethroplasty has very promising results for short strictures $(<2 \mathrm{~cm})$ and longer strictures $(2-4 \mathrm{~cm})$ residing in the proximal bulbar urethra, with a success rate around $90 \%{ }^{6-9}$ For longer strictures $(2-4 \mathrm{~cm})$ residing in the distal bulb, augmentation techniques are preferred since the anastomosis would be mostly on tension; however, the success rates are lower on using augmentation procedures. ${ }^{6-9,60}$

According to the AUA guidelines, graft onlay urethroplasty can be the procedure of choice in long strictures, whether through single or multistage techniques. Noteworthy, the SIU advises against the tubularized grafts while the AUA recommends, in specific, against the single-stage tubularized grafts. ${ }^{5-9}$ Flaps are less preferred in comparison to grafts considering the lesser mobility and comparable success rates, as per the SIU recommendations. ${ }^{6-9}$ Regarding the graft choice, oral mucosa is the best choice, while hairbearing skin, including scrotal, should not be used. ${ }^{5-9}$ Allografts, animal grafts, and synthesized grafts should be only limited to experimental procedures. ${ }^{5-9}$

\section{Meatal, fossa navicularis, and penile urethra strictures}

For meatal and fossa navicularis strictures, the AUA recommends performing meatotomy or urethral dilatation as initial management, while urethroplasty is only recommended in recurrent strictures. ${ }^{5}$ In the case of hypospadias-associated strictures, urethroplasty is the recommended initial management. ${ }^{6-9}$ For penile urethral strictures, urethroplasty should be the initial treatment and multistage procedures are more successful in complex strictures compared to the single staged. ${ }^{5-9}$ For substitution urethroplasty, only flaps should be used for penile strictures. $^{5-9}$

\section{CONCLUSION}

Although EPA and augmentation/substitution urethraplasties have considerable long term success rates, the EPA procedures have a controversial influence on sexual function, which may be unacceptable to some reconstructive urologists. In general, there are a few large scales, multi center studies that can produce high quality evidence. There is an urge to develop higher grade research in terms of ideal management of urethral strictures.

Funding: No funding sources Conflict of interest: None declared Ethical approval: Not required

\section{REFERENCES}

1. Bayne DB, Gaither TW, Awad MA, Murphy GP, Osterberg EC, Breyer BN. Guidelines of guidelines: a review of urethral stricture evaluation, management, and follow-up. Transl Androl Urol. 2017;6(2):288-294.

2. Lumen N, Hoebeke P, Willemsen P, De Troyer B, Pieters R, Oosterlinck W. Etiology of urethral stricture disease in the 21st century. J Urol. 2009; 182(3):983-7.

3. Santucci RA, Joyce GF, Wise M. Male urethral stricture disease. J Urol. 2007;177(5):1667-74.

4. Mundy AR. Words of wisdom. Re: Outcome of dorsal buccal graft urethroplasty for recurrent urethral strictures. Eur Urol. 2009;55(4):991-2.

5. Wessells H, Angermeier KW, Elliott S. Male urethral stricture: American urological association guideline. J Urol. 2017;197(1):182-90.

6. Angermeier KW, Rourke KF, Dubey D, Forsyth RJ, Gonzalez CM. SIU/ICUD Consultation on Urethral Strictures: Evaluation and Follow-up. Urol. 2014; 83(3):S8-17.

7. Buckley JC, Heyns C, Gilling P, Carney J. SIU/ICUD consultation on urethral strictures: dilation, internal urethrotomy, and stenting of male anterior urethral strictures. Urol. 2014;83(3, Supplement):S18-S22.

8. Chapple C, Andrich D, Atala A, et al. SIU/ICUD Consultation on urethral strictures: the management of anterior urethral stricture disease using substitution urethroplasty. Urol. 2014;83(3):S3-47.

9. Kaplan GW, Brock JW, Fisch M, Koraitim MM, Snyder HM. SIU/ICUD Consultation on urethral strictures: urethral strictures in children. Urol. 2014; 83(3):S71-3.

10. Goulao B, Carnell S, Shen J. Surgical treatment for recurrent bulbar urethral stricture: a randomised open-label superiority trial of open urethroplasty 
versus endoscopic urethrotomy (the OPEN Trial). Eur Urol. 2020;78(4):572-80.

11. Gallegos MA, Santucci RA. Advances in urethral stricture management. F1000Res. 2016;5:2913.

12. Gallentine ML, Morey AF. Imaging of the male urethra for stricture disease. Urol Clin North Am. 2002;29(2):361-72.

13. Goonesinghe SK, Hillary CJ, Nicholson TR, Osman NI, Chapple CR. Flexible cystourethroscopy in the follow-up of posturethroplasty patients and characterisation of recurrences. Eur Urol. 2015;68 (3):523-9.

14. Erickson BA, Breyer BN, McAninch JW. Changes in uroflowmetry maximum flow rates after urethral reconstructive surgery as a means to predict for stricture recurrence. J Urol. 2011;186(5):1934-7.

15. Bach $\mathrm{P}$, Rourke $\mathrm{K}$. Independently interpreted retrograde urethrography does not accurately diagnose and stage anterior urethral stricture: the importance of urologist-performed urethrography. Urol. 2014;83(5):1190-3.

16. Heidenreich A, Derschum W, Bonfig R, Wilbert DM. Ultrasound in the evaluation of urethral stricture disease: a prospective study in 175 patients. $\mathrm{Br} \mathrm{J}$ Urol. 1994;74(1):93-8.

17. Verges J, Desgrez JP, Claude JM, Cabane H. Internal urethrotomy. Resection of urethral stricture over 5 years follow-up. Ann Urol. 1990;24(1):73-5.

18. Steenkamp JW, Heyns CF, de Kock ML. Internal urethrotomy versus dilation as treatment for male urethral strictures: a prospective, randomized comparison. J Urol. 1997;157(1):98-101.

19. Eltahawy EA, Virasoro R, Schlossberg SM, McCammon KA, Jordan GH. Long-Term Followup for Excision and Primary Anastomosis for Anterior Urethral Strictures. J Urol. 2007;177(5):1803-6.

20. Wong SS, Aboumarzouk OM, Narahari R, O'Riordan A, Pickard R. Simple urethral dilatation, endoscopic urethrotomy, and urethroplasty for urethral stricture disease in adult men. Cochrane Database Syst Rev. 2012;12:CD006934.

21. Greenwell TJ, Castle C, Andrich DE, MacDonald JT, Nicol DL, Mundy AR. Repeat urethrotomy and dilation for the treatment of urethral stricture are neither clinically effective nor cost-effective. J Urol. 2004;172(1):275-7.

22. Wright JL, Wessells H, Nathens AB, Hollingworth $\mathrm{W}$. What is the most cost-effective treatment for 1 to 2-cm bulbar urethral strictures: societal approach using decision analysis. Urol. 2006;67(5):889-93.

23. Rourke KF, Jordan GH. Primary urethral reconstruction: the cost minimized approach to the bulbous urethral stricture. J Urol. 2005;173(4):120610 .

24. Barbagli G, Kulkarni SB, Fossati N. Long-term followup and deterioration rate of anterior substitution urethroplasty. J Urol. 2014;192(3):80813.

25. Cooperberg MR, McAninch JW, Alsikafi NF, Elliott SP. Urethral reconstruction for traumatic posterior urethral disruption: outcomes of a 25-year experience. J Urol. 2007;178(5):2006-10.

26. Barbagli G, De Angelis M, Romano G, Lazzeri M. Long-term followup of bulbar end-to-end anastomosis: a retrospective analysis of 153 patients in a single center experience. J Urol. 2007;178(6): 2470-3.

27. Andrich DE, Dunglison N, Greenwell TJ, Mundy AR. The long-term results of urethroplasty. J Urol. 2003;170(1):90-2.

28. Jordan G, McCammon K. Surgery of the penis and urethra. United States: Elsevier Saunders; 2012.

29. Morey AF, Kizer WS. Proximal bulbar urethroplasty via extended anastomotic approach--what are the limits?. J Urol. 2006;175(6):2145-9.

30. Morey AF, Watkin N, Shenfeld O, Eltahawy E, Giudice C. SIU/ICUD Consultation on Urethral Strictures: Anterior urethra-primary anastomosis. Urol. 2014;83(3):S23-6.

31. Palminteri E, Berdondini E, De Nunzio C. The impact of ventral oral graft bulbar urethroplasty on sexual life. Urol. 2013;81(4):891-8.

32. Erickson BA, Granieri MA, Meeks JJ, McVary KT, Gonzalez CM. Prospective analysis of ejaculatory function after anterior urethral reconstruction. J Urol. 2010;184(1):238-42.

33. Al-Qudah HS, Santucci RA. Extended complications of urethroplasty. Int Braz J Urol. 2005;31(4):315-23.

34. Blaschko SD, Sanford MT, Cinman NM, McAninch JW, Breyer BN. De novo erectile dysfunction after anterior urethroplasty: a systematic review and metaanalysis. BJU Int. 2013;112(5):655-63.

35. Haines T, Rourke KF. The effect of urethral transection on erectile function after anterior urethroplasty. World J Urol. 2017;35(5):839-45.

36. Bugeja S, Andrich DE, Mundy AR. Non-transecting bulbar urethroplasty. Transl Androl Urol. 2015;4(1): 41-50.

37. el-Kasaby AW, Fath-Alla M, Noweir AM, el-Halaby MR, Zakaria W, el-Beialy MH. The use of buccal mucosa patch graft in the management of anterior urethral strictures. J Urol. 1993;149(2):276-8.

38. Bürger RA, Müller SC, el-Damanhoury $H$, Tschakaloff A, Riedmiller H, Hohenfellner R. The buccal mucosal graft for urethral reconstruction: a preliminary report. J Urol. 1992;147(3):662-4.

39. Maarouf AM, Elsayed ER, Ragab A. Buccal versus lingual mucosal graft urethroplasty for complex hypospadias repair. J Pediatr Urol. 2013;9(6):754-8.

40. Mangera A, Patterson JM, Chapple CR. A systematic review of graft augmentation urethroplasty techniques for the treatment of anterior urethral strictures. Eur Urol. 2011;59(5):797-814.

41. Kellner DS, Fracchia JA, Armenakas NA. Ventral onlay buccal mucosal grafts for anterior urethral strictures: long-term followup. J Urol. 2004;171(2): 726-9.

42. Wessells H. Ventral onlay graft techniques for urethroplasty. Urol Clin North Am. 2002;29(2):3817. 
43. Kulkarni S, Barbagli G, Sansalone S, Lazzeri M. One-sided anterior urethroplasty: a new dorsal onlay graft technique. BJU Int. 2009;104(8):1150-5.

44. Barbagli G, Palminteri E, Guazzoni G, Cavalcanti A. Bulbar urethroplasty using the dorsal approach: current techniques. Int Braz J Urol. 2003;29(2):15561.

45. Barbagli G, Selli C, di Cello V, Mottola A. A onestage dorsal free-graft urethroplasty for bulbar urethral strictures. Br J Urol. 1996;78(6):929-32.

46. Andrich DE, Leach CJ, Mundy AR. The Barbagli procedure gives the best results for patch urethroplasty of the bulbar urethra. BJU Int. 2001; 88(4):385-9.

47. Elliott SP, Metro MJ, McAninch JW. Long-term followup of the ventrally placed buccal mucosa onlay graft in bulbar urethral reconstruction. J Urol. 2003; 169(5):1754-7.

48. Dubey D, Kumar A, Bansal P. Substitution urethroplasty for anterior urethral strictures: a critical appraisal of various techniques. BJU Int. 2003;91(3): 215-8.

49. Barbagli G, Palminteri E, Guazzoni G, Montorsi F, Turini D, Lazzeri M. Bulbar urethroplasty using buccal mucosa grafts placed on the ventral, dorsal or lateral surface of the urethra: are results affected by the surgical technique?. J Urol. 2005;174(3):955-7.

50. Palminteri E, Manzoni G, Berdondini E. Combined dorsal plus ventral double buccal mucosa graft in bulbar urethral reconstruction. Eur Urol. 2008;53 (1):81-9.

51. Joshi P, Kaya C, Kulkarni S. Approach to bulbar urethral strictures: Which technique and when?. Turk J Urol. 2016;42(2):53-9.

52. Kulkarni S, Kulkarni J, Kirpekar DJJU. A new technique of urethroplasty for balanitis xerotica obliterans. J Urol. 2000;163:352.

53. Kulkarni SB, Joshi PM, Venkatesan K. Management of panurethral stricture disease in India. The J Urol. 2012;188(3):824-30.
54. Dubey D, Sehgal A, Srivastava A, Mandhani A, Kapoor R, Kumar A. Buccal mucosal urethroplasty for balanitis xerotica obliterans related urethral strictures: the outcome of 1 and 2-stage techniques. J Urol. 2005;173(2):463-6.

55. Devine CJ, Franz JP, Horton CE. Evaluation and treatment of patients with failed hypospadias repair. J Urol. 1978;119(2):223-6.

56. Stecker JF, Horton CE, Devine CJ, McCraw JB. Hypospadias cripples. Urol Clin North Am. 1981;8 (3):539-44.

57. Barbagli G, Palminteri E, Lazzeri M, Turini D. Interim outcomes of dorsal skin graft bulbar urethroplasty. J Urol. 2004;172:1365-7.

58. Kozinn SI, Harty NJ, Zinman L, Buckley JC. Management of complex anterior urethral strictures with multistage buccal mucosa graft reconstruction. Urol. 2013;82(3):718-22.

59. Meeks JJ, Erickson BA, Gonzalez CM. Staged reconstruction of long segment urethral strictures in men with previous pediatric hypospadias repair. J Urol. 2009;181(2):685-9.

60. Kluth LA, Dahlem R, Reiss P, et al. Short-term outcome and morbidity of different contemporary urethroplasty techniques--a preliminary comparison. J Endourol. 2013;27(7):925-9.

Cite this article as: Basaif WS, Madkhali AA, Almania AI, Mohammed RA, Alshahrani MM, Jabir AMA, et al. Urethroplasty in the management of urethral strictures: a literature review. Int J Community Med Public Health 2021;8:915-21. 